\title{
Adjuvant treatment with tumor-targeting Salmonella typhimurium A1-R reduces recurrence and increases survival after liver metastasis resection in an orthotopic nude mouse model
}

\author{
Takashi Murakami ${ }^{1,2,3}$, Yukihiko Hiroshima ${ }^{1,2,3}$, Ming Zhao', Yong Zhang1, Takashi \\ Chishima ${ }^{3}$, Kuniya Tanaka ${ }^{3}$, Michael Bouvet ${ }^{2}$, Itaru Endo ${ }^{3}$ and Robert M. Hoffman ${ }^{1,2}$ \\ ${ }^{1}$ AntiCancer, Inc., San Diego, California, USA \\ 2 Department of Surgery, University of California, San Diego, California, USA \\ ${ }^{3}$ Department of Gastroenterological Surgery, Graduate School of Medicine, Yokohama City University, Japan \\ Correspondence to: Robert M. Hoffman, email: all@anticancer.com \\ Keywords: liver metastasis, colon cancer, RFP, nude mice, orthotopic models \\ Received: August 07, $2015 \quad$ Accepted: October 04, $2015 \quad$ Published: October 19, 2015
}

This is an open-access article distributed under the terms of the Creative Commons Attribution License, which permits unrestricted use, distribution, and reproduction in any medium, provided the original author and source are credited.

\section{ABSTRACT}

Colon cancer liver metastasis is often the lethal aspect of this disease. Wellisolated metastases are candidates for surgical resection, but recurrence is common. Better adjuvant treatment is therefore needed to reduce or prevent recurrence. In the present study, HT-29 human colon cancer cells expressing red fluorescent protein (RFP) were used to establish liver metastases in nude mice. Mice with a single liver metastasis were randomized into bright-light surgery (BLS) or the combination of BLS and adjuvant treatment with tumor-targeting $S$. typhimurium A1-R. Residual tumor fluorescence after BLS was clearly visualized at high magnification by fluorescence imaging. Adjuvant treatment with $S$. typhimurium A1-R was highly effective to increase survival and disease-free survival after BLS of liver metastasis. The results suggest the future clinical potential of adjuvant $S$. typhimurium A1-R treatment after liver metastasis resection.

\section{INTRODUCTION}

Colon cancer liver metastasis is often the lethal aspect of this disease [1]. Well-isolated metastases are candidates for surgical resection, but recurrence is common [2]. Better adjuvant treatment is therefore needed to reduce or prevent recurrence.

Bacterial therapy of cancer has a long history [3-5]. The bacteria, now known as Streptococcus pyogenes [3-5], was found in cancer patients who had remission and was used for therapy in the late $19^{\text {th }}$ and early $20^{\text {th }}$ centuries [35], especially under William B. Coley.

Hoption Cann et al. [5] compared patient outcome with early bacterial treatment to modern chemotherapy and found the 10-year survival rates were comparable [5]. Beginning in the middle of the last century, bacteria were used for cancer therapy in animal models [6-18]. Bifidobacterium [18] and Clostridium [19], obligate anaerobes which replicate only in necrotic areas of tumors, had anti-tumor efficacy in mouse tumor models. Spores of Clostridium novyi, without its lethal toxin (C. novyi no toxin $[\mathrm{NT}]$ ), were recently used in a patient with leiomyosarcoma causing a metastatic lesion to regress after intratumor administration [20].

Salmonella typhimurium (S. typhimurium) is a facultative anaerobe, which in contrast to obligate anaerobes, allows growth in the viable regions as well as necrotic regions of tumors [20]. S. typhimuriumVNP20009, with msbB and purI mutations, was found safe in a Phase I clinical trial of metastatic melanoma and renal carcinoma [21].

The tumor-targeting S. typhimurium A1-R strain developed by our laboratory has higher tumor colonization efficacy and antitumor efficacy than S. typhimuriumVNP20009 [22], possibly because it has fewer attenuation mutations. S. typhimurium A1-R is auxotrophic for Leu-Arg, which prevents it from mounting a continuous infection in normal tissues. S. typhimurium A1-R was able 
to inhibit or eradicate primary and metastatic tumors as monotherapy in nude mouse models of prostate [23, 24], breast [25-27], lung [28, 29], pancreatic [30-34], ovarian $[35,36]$ stomach [37], and cervical cancer [38], as well as sarcoma [39-41] and glioma [42,43], all of which are highly aggressive tumor models.

The present report demonstrates adjuvant treatment efficacy of S. typhimurium A1-R after bright-light surgery (BLS) of liver metastasis.

\section{RESULTS AND DISCUSSION}

\section{BLS cannot resect the entire liver metastasis}

Residual tumor fluorescence was detected on the surgical resection bed after BLS of HT-29-RFP liver metastasis (Figure 1). There was no significant difference in residual tumor area between the control group $(0.237 \pm$ $\left.0.094 \mathrm{~mm}^{2}\right)$ and BLS group $\left(0.250 \pm 0.120 \mathrm{~mm}^{2}\right)$.

\section{Adjuvant treatment with $S$. typhimurium A1-R increases survival after BLS}

Adjuvant $S$. typhimurium A1-R treatment after BLS significantly prolonged both disease-free $(P=0.005$; Figure 2A) and overall survival ( $P=0.010$; Figure 2B).

Liver metastasis of colon cancer is the major lethal event of this disease. In many cases, diffuse liver metastasis is inoperable. However, isolated liver metastasis provides an opportunity for resection, but
BLS very often results in residual cancer cells. The present report demonstrates that $S$. typhimurium A1-R can eradicate sufficient residual cancer cells after BLS to significantly increase disease-free survival and overall survival. Future experiments will also use $S$. typhimurium A1-R as neoadjuvant chemotherapy to convert inoperable tumors to those that are resectable.

In a recent study, we found that Salmonella typhimurium A1-R was active as monotherapy on liver metastasis in the orthotopic HT-29 mouse model. The results of that study demonstrated the potential of $S$. typhimurium A1-R targeting of liver metastasis [44].

The recurrence rate after liver metastasis resection is high, up to $75 \%[1,2,45]$. Adjuvant therapy for colon cancer liver metastasis is usually based on 5-fluorouracil and oxaliplatin and it is not highly effective $[1,2,45]$. Therefore, novel approaches are necessary to improve adjuvant therapy of colon cancer liver metastasis.

The present study indicated that S. typhimuirum A1-R can be curative as adjuvant treatment for liver metastasis. Clinical trials of $S$. typhimurium A1-R for adjuvant therapy of patients with liver metastasis resection would have high potential.

Previously developed concepts and strategies of highly selective tumor targeting [46-51] can take advantage of bacterial targeting of tumors, including tissue-selective therapy which focuses on unique properties of normal and tumor tissues [46, 51]. S. typhimurium A1-R can possibly overcome de-differentiation of a tumor leading to resistance to targeted chemotherapy, where the targeted protein or pathway may no longer be expressed [51], since S. typhimurium A1-R does not depend on
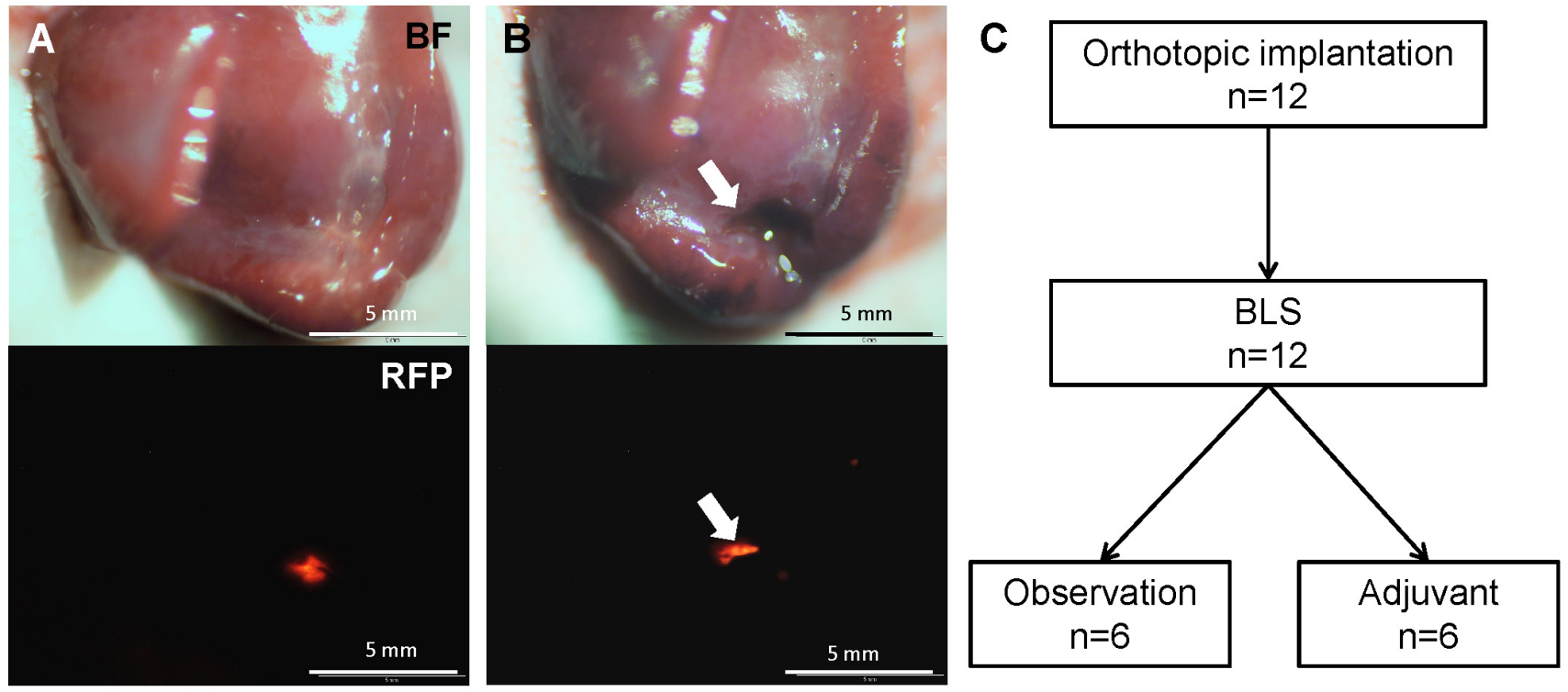

Figure 1: Efficacy of BLS alone on liver metastasis. A. Tumor fluorescence was clearly detected before BLS. B. Tumor fluorescence still remained on the surgical resection bed (arrows) after BLS. C. Schematic diagram of the experimental design for adjuvant S. typhimurium A1-R treatment. Twelve mice were randomized into observation $(n=6)$ and adjuvant groups $(n=6)$. $B F=$ bright field. 

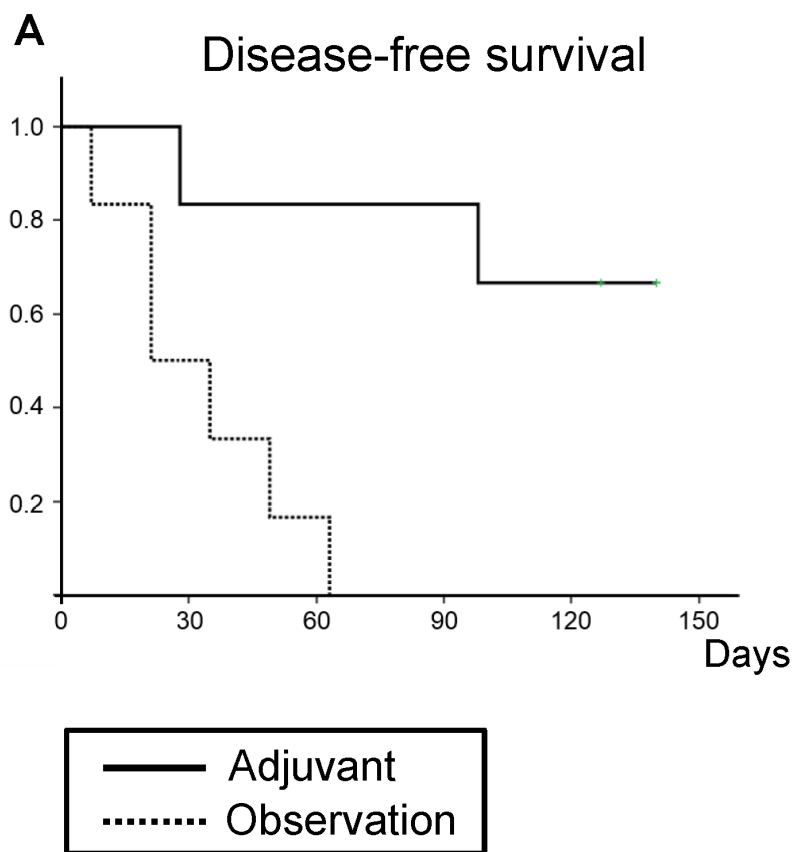
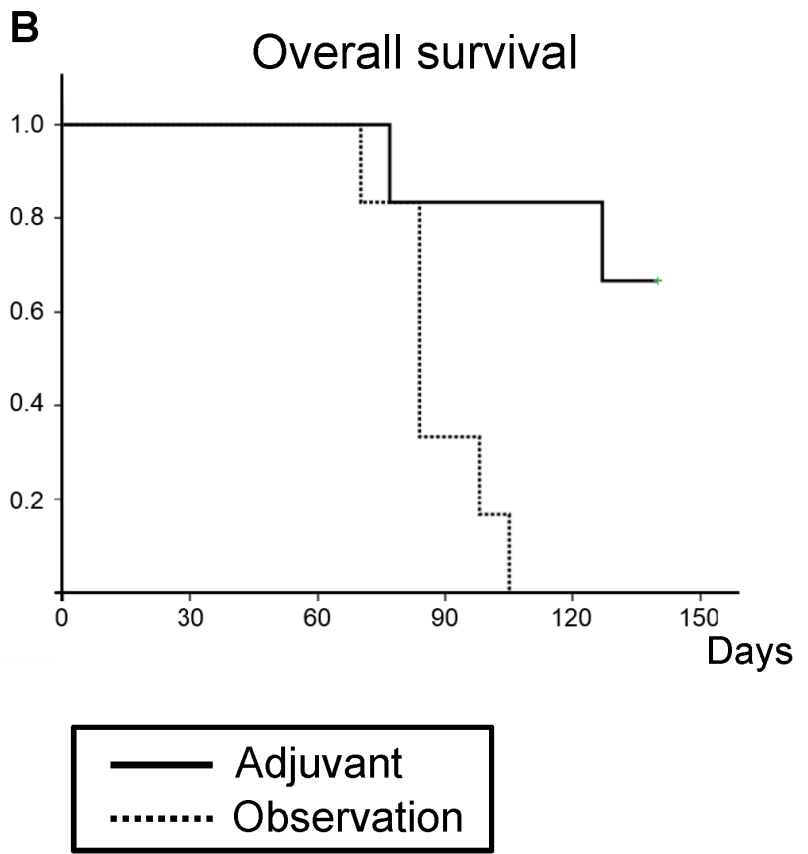

Figure 2: Efficacy of adjuvant $S$. typhimurium A1-R treatment on disease-free and overall survival according to the Kaplan-Meier method. Mice in the adjuvant group had reduced recurrence (A) and increased survival (B) compared to those in the untreated control group.

such targets $[46,48]$. S. typhimurium A1-R may also be effectively combined with teratogens which could selectively affect cancer cells that are dedifferentiated [47]. Since S. typhimurium A1-R can decoy quiescent cancer cells to begin to cycle, $S$. typhimurium A1-R could be effectively combined with agents which selectively target proliferating cancer cells [49], where normal cells are protected by agents which induce wild type p53 [50].

\section{MATERIALS AND METHODS}

Mice

Athymic $n u / n u$ nude mice (AntiCancer Inc., San Diego, CA), 4-6 weeks old, were used in this study. All animal studies were conducted with an AntiCancer Institutional Animal Care and Use Committee (IACUC)protocol specifically approved for this study and in accordance with the principals and procedures outlined in the National Institute of Health Guide for the Care and Use of Animals under Assurance Number A3873-1. In order to minimize any suffering of the animals, anesthesia and analgesics were used for all surgical experiments. Animals were anesthetized by subcutaneous injection of a $0.02 \mathrm{ml}$ solution of $20 \mathrm{mg} / \mathrm{kg}$ ketamine, $15.2 \mathrm{mg} /$ $\mathrm{kg}$ xylazine, and $0.48 \mathrm{mg} / \mathrm{kg}$ acepromazine maleate. The response of animals during surgery was monitored to ensure adequate depth of anesthesia. The animals were observed on a daily basis and humanely sacrificed by $\mathrm{CO}_{2}$ inhalation when they met the following humane endpoint criteria: prostration, significant body weight loss, difficulty breathing, rotational motion and body temperature drop. The use of animals was necessary to evaluate $S$. typhimurium A1-R efficacy in vivo. Animals were housed with no more than 5 per cage. Animals were housed in a barrier facility on a high efficiency particulate arrestance (HEPA)-filtered rack under standard conditions of 12-hour light/dark cycles. The animals were fed an autoclaved laboratory rodent diet.

\section{Cell line}

The human colon cancer cell line HT-29, [52, 53] was maintained in DMEM (Irvine Scientific, Irvine, CA) supplemented with heat-inactivated $10 \%$ fetal bovine serum (FBS) (Gemini Biologic Products, Calabasas, CA), $2 \mathrm{mM}$ glutamine, 100 units/ml penicillin, $100 \mu \mathrm{g} /$ $\mathrm{ml}$ streptomycin, and $0.25 \mu \mathrm{g} / \mathrm{ml}$ amphotericin B (Life Technologies, Inc., Grand Island, NY). The cells were incubated at $37^{\circ} \mathrm{C}$ in $5 \% \mathrm{CO} 2$.

\section{Establishment of RFP-labeled HT29}

The pDsRed-2 vector (Clontech Laboratories Inc., Palo Alto, CA) expressing RFP and the neomycinresistance gene was used to stably transfect HT-29 cells to express RFP. For RFP gene transfection, $25 \%$ confluent HT-29 cells were incubated with a mixture of retroviral 
supernatants of PT67-RFP packaging cells and DMEM for $24 \mathrm{~h}$. Fresh medium was replenished at this time, and cells were allowed to grow in the absence of retrovirus for $12 \mathrm{~h}$. This procedure was repeated until high levels of RFP expression were achieved. Cells were then harvested with trypsin-EDTA and subcultured into selective medium that contained G418 (200 $\mu \mathrm{g} / \mathrm{ml})$ (Geneticin, Invitrogen Corp., Carlsbad, CA). The level of G418 was increased to $2,000 \mu \mathrm{g} / \mathrm{ml}$ stepwise. Clones expressing high levels of RFP were isolated and were amplified and transferred using conventional culture methods. High RFP-expression clones were isolated in the absence of G418 for 10 passages to select for stable expression of RFP $[52,54$, 55].

\section{Preparation of S. typhimurium A1-R}

GFP-expressing $S$. typhimurium A1-R bacteria (AntiCancer Inc.) were grown overnight on LB medium (Fisher Sci., Hanover Park, IL, USA) and then diluted 1:10 in LB medium. Bacteria were harvested at late-log phase, washed with PBS, and then diluted in PBS [23].

\section{Initial establishment of liver metastases}

HT-29-RFP cells were harvested by trypsinization and washed twice with serum-free medium. Cells $\left(5 \times 10^{5}\right.$ in $50 \mu \mathrm{l}$ serum-free medium with $50 \%$ Matrigel) were injected into the superior and inferior pole of the spleen in mice. Three weeks after injection, liver metastases were established.

\section{Surgical orthotopic implantation of liver metastasis}

Established liver metastases were resected and cut into blocks $\left(3 \mathrm{~mm}^{3}\right)$. A single tumor fragment was orthotopically implanted into the left lobe of the liver in other nude mice. Four weeks later, liver metastasis was observed in the implanted site.

\section{Efficacy for adjuvant $S$. typhimurium A1-R treatment on liver metastasis after resection}

Four weeks after orthotopic implantation to the liver, the liver metastasis was resected along the tumor margin under bright light. Twelve mice treated with standard bright-light surgery (BLS) were randomized into 2 groups: a control group $(\mathrm{n}=6)$ and an $S$. typhimurium A1-R adjuvant group $(\mathrm{n}=6)$. S. typhimurium A1-R $(5 \times$ $10^{7} \mathrm{CFU} /$ body, iv, weekly, 3 weeks) was administered to the mice as adjuvant treatment beginning one week after BLS. Tumor fluorescence was visualized with the OV100 variable magnification small animal fluorescence imaging system (Olympus Corp., Tokyo, Japan) before and right after BLS. Recurrence was monitored by weekly noninvasive tumor fluorescence evaluation with the LT-9900 Illumatool (Lightools Research, Encinitas, CA, USA) until the end of the experiment.

\section{Statistical analysis}

SPSS statistics (version 21.0) was used for all statistical analyses (IBM, New York City, NY, USA). Survival curves were constructed using the KaplanMeier method and compared using the log-rank test. A probability value of $P<0.05$ was considered statistically significant.

\section{ACKNOWLEDGEMENT}

This study was supported by National Cancer Institute grant CA132971 and CA142669 and JSPS KAKENHI grant 26830081 to $\mathrm{YH}, 26462070$ to IE and 24592009 to KT. The funders had no role in study design, data collection and analysis, decision to publish, or preparation of the manuscript.

\section{CONFLICTS OF INTEREST}

M.Z. and Y.Z. are employees of AntiCancer Inc. T.M. and R.M.H. are unsalaried associates of AntiCancer Inc. There are no other competing financial interests.

\section{Dedication}

This paper is dedicated to the memory of A. R. Moossa, M.D.

\section{REFERENCES}

1. Rothbarth J, van de Velde CJ. Treatment of liver metastases of colorectal cancer. Ann Oncol 2005;16 Supp1 2:ii144-49.

2. de Jong MC, Pulitano C, Ribero D, Strub J, Mentha G, Schulick RD, Choti MA, Aldrighetti L, Capussotti L, Pawlik TM. Rates and patterns of recurrence following curative intent surgery for colorectal liver metastasis: an international multi-institutional analysis of 1669 patients. Ann Surg 2009;250:440-448.

3. William Coley. Available at: https://en.wikipedia.org/wiki/ William_Coley [last accessed 12 December 2013].

4. Forbes NS. Engineering the perfect (bacterial) cancer therapy. Nat Rev Cancer 2010;10:785-94.

5. Hoption Cann SA, van Netten JP, van Netten C. Dr William Coley and tumour regression: a place in history or in the future. Postgrad Med J 2003;79:672-80.

6. Richardson MA, Ramirez T, Russell NC, Moye LA. Coley toxins immunotherapy: a retrospective review. Altern Ther 
Health Med 1999;5(3):42-7.

7. Gericke D, Engelbart K. Oncolysis by clostridia. II. Experiments on a tumor spectrum with a variety of clostridia in combination with heavy metal. Cancer Res 1964; 24:217-21.

8. Moese JR, Moese G. Oncolysis by clostridia. I. Activity of Clostridium butyricum (M-55) and other nonpathogenic clostridia against the Ehrlich carcinoma. Cancer Res 1964; 24:212-6.

9. Thiele EH, Arison RN, Boxer GE. Oncolysis by clostridia. III. Effects of clostridia and chemotherapeutic agents on rodent tumors. Cancer Res 1964; 24:222-33.

10. Kohwi Y, Imai K, Tamura Z, Hashimoto Y. Antitumor effect of Bifidobacterium infantis in mice. Gan 1978; 69:613-8.

11. Kimura NT, Taniguchi S, Aoki K, Baba T. Selective localization and growth of Bifidobacterium bifidum in mouse tumors following intravenous administration. Cancer Res 1980; 40:2061-8.

12. Fox ME, Lemmon MJ, Mauchline ML, Davis TO, Giaccia AJ, Minton NP, Brown JM. Anaerobic bacteria as a delivery system for cancer gene therapy: in vitro activation of 5-fluorocytosine by genetically engineered clostridia. Gene Ther 1996; 3:173-8.

13. Lemmon MJ, Van Zijl P, Fox ME, Mauchline ML, Giaccia AJ, Minton NP, Brown JM. Anaerobic bacteria as a gene delivery system that is controlled by the tumor microenvironment. Gene Ther 1997; 4:791-6.

14. Brown JM, Giaccia AJ. The unique physiology of solid tumors: opportunities (and problems) for cancer therapy. Cancer Res 1998; 58:1408-16.

15. Low KB, Ittensohn M, Le T, Platt J, Sodi S, Amoss M, Ash O, Carmichael E, Chakraborty A, Fischer J, Lin SL, Luo X, Miller SI, Zheng L, King I, Pawelek JM, Bermudes D. Lipid A mutant Salmonella with suppressed virulence and TNFalpha induction retain tumor-targeting in vivo. Nat Biotechnol 1999; 17:37-41.

16. Clairmont $\mathrm{C}$, Lee KC, Pike J, Ittensohn M, Low KB, Pawelek J, Bermudes D, Brecher SM, Margitich D, Turnier J, Li Z, Luo X, King I, Zheng LM. Biodistribution and genetic stability of the novel antitumor agent VNP20009, a genetically modified strain of Salmonella typhimurium. J Infect Dis 2000; 181:1996-2002.

17. Sznol M, Lin SL, Bermudes D, Zheng LM, King I. Use of preferentially replicating bacteria for the treatment of cancer. J Clin Invest 2000; 105:1027-30.

18. Yazawa K, Fujimori M, Nakamura T, Sasaki T, Amano J, Kano Y, Taniguchi S. Bifidobacterium longum as a delivery system for gene therapy of chemically induced rat mammary tumors. Breast Cancer Res Treat 2001; 66:16570 .

19. Dang LH, Bettegowda C, Huso DL, Kinzler KW, Vogelstein B. Combination bacteriolytic therapy for the treatment of experimental tumors. Proc Natl Acad Sci USA
2001; 98:15155-60.

20. Roberts NJ, Zhang L, Janku F, Collins A, Bai RY, Staedtke V, Rusk AW, Tung D, Miller M, Roix J, Khanna KV, Murthy R, Benjamin RS, et al. Intratumoral injection of Clostridium novyi-NT spores induces antitumor responses. Sci Transl Med 2014; 6:249ra111.

21. Toso JF, Gill VJ, Hwu P, Marincola FM, Restifo NP, Schwartzentruber DJ, Sherry RM, Topalian SL, Yang JC, Stock F, Freezer LJ, Morton KE, Seipp C, et al. Phase I study of the intravenous administration of attenuated Salmonella typhimurium to patients with metastatic melanoma. J Clin Oncol 2002; 20:142-52.

22. Zhang Y, Zhang N, Zhao M, Hoffman RM. Comparison of the selective targeting efficacy of Salmonella typhimurium A1-R and VNP20009 on the Lewis lung carcinoma in nude mice. Oncotarget 2015; 6:14625-31.

23. Zhao M, Yang M, Li XM, Jiang P, Baranov E, Li S, Xu M, Penman S, Hoffman RM. Tumor-targeting bacterial therapy with amino acid auxotrophs of GFP-expressing Salmonella typhimurium. Proc Natl Acad Sci USA 2005;102:755-60.

24. Zhao M, Geller J, Ma H, Yang M, Penman S, Hoffman RM. Monotherapy with a tumor-targeting mutant of Salmonella typhimurium cures orthotopic metastatic mouse models of human prostate cancer. Proc Natl Acad Sci USA 2007; 104:10170-4.

25. Zhao M, Yang M, Ma H, Li X, Tan X, Li S, Yang $Z$, Hoffman RM.Targeted therapy with a Salmonella typhimurium leucine-arginine auxotroph cures orthotopic human breast tumors in nude mice. Cancer Res 2006; 66:7647-52.

26. Zhang Y, Tome Y, Suetsugu A, Zhang L, Zhang N, Hoffman RM, Zhao M. Determination of the optimal route of administration of Salmonella typhimurium A1-R to target breast cancer in nude mice. Anticancer Res 2012; 32:2501-8.

27. Zhang Y, Miwa S, Zhang N, Hoffman RM, Zhao M. Tumor-targeting Salmonella typhimurium A1-R arrests growth of breast-cancer brain metastasis. Oncotarget 2015; 6:2615-22.

28. Uchugonova A, Zhao M, Zhang Y, Weinigel M, König K, Hoffman RM. Cancer-cell killing by engineered Salmonella imaged by multiphoton tomography in live mice. Anticancer Res 2012;32:4331-7.

29. Liu F, Zhang L, Hoffman RM, Zhao M. Vessel destruction by tumor-targeting Salmonella typhimurium A1-R is enhanced by high tumor vascularity. Cell Cycle 2010;9:4518-24.

30. Nagakura C, Hayashi K, Zhao M, Yamauchi K, Yamamoto N, Tsuchiya H, Tomita K, Bouvet M, Hoffman RM. Efficacy of a genetically-modified Salmonella typhimurium in an orthotopic human pancreatic cancer in nude mice. Anticancer Res 2009;29:1873-8.

31. Yam C, Zhao M, Hayashi K, Ma H, Kishimoto $H$, McElroy M, Bouvet M, Hoffman RM. Monotherapy with 
a tumor-targeting mutant of S. typhimurium inhibits liver metastasis in a mouse model of pancreatic cancer. J Surg Res 2010;164:248-55.

32. Hiroshima Y, Zhao M, Zhang Y, Maawy A, Hassanein MK, Uehara F, Miwa S, Yano S, Momiyama M, Suetsugu A, Chishima T, Tanaka K, Bouvet M, Endo I, Hoffman RM. Comparison of efficacy of Salmonella typhimurium A1-R and chemotherapy on stem-like and non-stem human pancreatic cancer cells. Cell Cycle 2013;12:2774-80.

33. Hiroshima Y, Zhao M, Maawy A, Zhang Y, Katz MH, Fleming JB, Uehara F, Miwa S, Yano S, Momiyama M, Suetsugu A, Chishima T, Tanaka K, Bouvet M, Endo I, Hoffman RM. Efficacy of Salmonella typhimurium A1-R versus chemotherapy on a pancreatic cancer patientderived orthotopic xenograft (PDOX). J Cell Biochem 2014;115:1254-61.

34. Hiroshima Y, Zhang Y, Murakami T, Maawy AA, Miwa S, Yamamoto M, Yano S, Sato S, Momiyama M, Mori R, Matsuyama R, Chishima T, Tanaka K, et al. Efficacy of tumor-targeting Salmonella typhimurium A1-R in combination with anti-angiogenesis therapy on a pancreatic cancer patient-derived orthotopic xenograph (PDOX) and cell line mouse models. Oncotarget 2014;5:12346-57.

35. Matsumoto Y, Miwa S, Zhang Y, Hiroshima Y, Yano S, Uehara F, Yamamoto M, Toneri M, Bouvet M, Matsubara H, Hoffman RM, Zhao M. Efficacy of tumor-targeting Salmonella typhimurium A1-R on nude mouse models of metastatic and disseminated human ovarian cancer. J Cell Biochem 2014; 115:1996-2003.

36. Matsumoto Y, Miwa S, Zhang Y, Zhao M, Yano S, Uehara F, Yamamoto M, Hiroshima Y, Toneri M, Bouvet M, Matsubara H, Tsuchiya H, Hoffman RM. Intraperitoneal administration of tumor-targeting Salmonella typhimurium A1-R inhibits disseminated human ovarian cancer and extends survival in nude mice. Oncotarget 2015;6:1136977.

37. Yano S, Zhang Y, Zhao M, Hiroshima Y, Miwa S, Uehara F, Kishimoto H, Tazawa H, Bouvet M, Fujiwara T, and Hoffman RM. Tumor-targeting Salmonella typhimurium A1-R decoys quiescent cancer cells to cycle as visualized by FUCCI imaging and become sensitive to chemotherapy. Cell Cycle 2014;13:3958-63.

38. Hiroshima Y, Zhang Y, Zhao M, Zhang N, Murakami T, Maawy A, Mii S, Uehara F, Yamamoto M, Miwa S, Yano S, Momiyama M, Mori R, et al. Tumor-targeting Salmonella typhimurium A1-R in combination with Trastuzumab eradicates HER-2-positive cervical cancer cells in patient-derived mouse models. PLoS One 2015; 10: e0120358.

39. Hayashi K, Zhao M, Yamauchi K, Yamamoto N, Tsuchiya H, Tomita K, Hoffman RM. Cancer metastasis directly eradicated by targeted therapy with a modified Salmonella typhimurium. J Cell Biochem 2009;106:992-8.

40. Hayashi K, Zhao M, Yamauchi K, Yamamoto N, Tsuchiya H, Tomita K, Kishimoto H, Bouvet M, Hoffman RM.
Systemic targeting of primary bone tumor and lung metastasis of high-grade osteosarcoma in nude mice with a tumor-selective strain of Salmonella typhimurium. Cell Cycle 2009; 8:870-5.

41. Miwa S, Zhang Y, Baek K-E, Uehara F, Yano S, Yamamoto M, Hiroshima Y, Matsumoto Y, Kimura H, Hayashi K, Yamamoto N, Tsuchiya H, Hoffman RM, Zhao M. Inhibition of spontaneous and experimental lung metastasis of soft-tissue sarcoma by tumor-targeting Salmonella typhimurium A1-R. Oncotarget 2014; 5:12849-61.

42. Kimura H, Zhang L, Zhao M, Hayashi K, Tsuchiya H, Tomita K, Bouvet M, Wessels J, Hoffman RM. Targeted therapy of spinal cord glioma with a genetically-modified Salmonella typhimurium. Cell Proliferation 2010;43:41-8.

43. Momiyama M, Zhao M, Kimura H, Tran B, Chishima T, Bouvet M, Endo I, Hoffman RM. Inhibition and eradication of human glioma with tumor-targeting Salmonella typhimurium in an orthotopic nude-mouse model. Cell Cycle 2012;11:628-32.

44. Murakami T, Hiroshima Y, Zhao M, Zhang Y, Chishima T, Tanaka K, Bouvet M, Endo I, Hoffman RM. Therapeutic efficacyof tumor-targeting Salmonella typhimurium A1-R on human colorectal cancer liver metastasis in orthotopic nude-mouse models. Oncotarget. 2015; doi: 10.18632/ oncotarget.5187 [Epub ahead of print].

45. Zhang W, Song T. The progress in adjuvant therapy after curative resection of liver metastasis from colorectal cancer. Drug Disc Therap 2014;8:194-200.

46. Blagosklonny MV. Matching targets for selective cancer therapy. Drug Discov Today 2003;8:1104-7.

47. Blagosklonny MV. Teratogens as anti-cancer drugs. Cell Cycle 2005;4:1518-21.

48. Blagosklonny MV. Treatment with inhibitors of caspases, that are substrates of drug transporters, selectively permits chemotherapy-induced apoptosis in multidrug-resistant cells but protects normal cells. Leukemia 2001;15:936-41.

49. Blagosklonny MV. Target for cancer therapy: proliferating cells or stem cells. Leukemia 2006;20:385-91.

50. Apontes $\mathrm{P}$, Leontieva $\mathrm{OV}$, Demidenko $\mathrm{ZN}$, Li F, Blagosklonny MV. Exploring long-term protection of normal human fibroblasts and epithelial cells from chemotherapy in cell culture. Oncotarget 2011;2:222-33.

51. Blagosklonny MV. Tissue-selective therapy of cancer. Br J Cancer 2003;89:1147-51.

52. Maawy AA, Hiroshima Y, Zhang Y, Luiken GA, Hoffman RM, Bouvet M. Polyethylene glycol (PEG) linked to near infrared (NIR) dyes conjugated to chimeric anticarcinoembryonic antigen (CEA) antibody enhances imaging of liver metastases in a nude-mouse model of human colon cancer. PLoS One 2014;9:e97965.

53. Ma H, Li X, Yang Z, Okuno S, Kawaguchi T, Yagi S, Bouvet M, Hoffman RM. High antimetastatic efficacy of MEN4901/T-0128, a novel camptothecin carboxymethyldextran conjugate. J Surg Res 2011;171:684- 
90.

54. Katz MH, Takimoto S, Spivack D, Moossa AR, Hoffman RM, Bouvet M. A novel red fluorescent protein orthotopic pancreatic cancer model for the preclinical evaluation of chemotherapeutics. J Surg Res 2003;113:151-60.

55. Metildi CA, Kaushal S, Snyder CS, Hoffman RM, Bouvet M. Fluorescence-guided surgery of human colon cancer increases complete resection resulting in cures in an orthotopic nude mouse model. J Surg Res 2013;179:87-93. 